DOI 10.17150/978-5-7253-3017-5.24

и.в. ОЛЕЙНИКОВ

УДК 316.324(571.53)

ББК С550(2P-4Иp)

ПРОЦЕССЫ ГЛОБАЛИЗАЦИИ И ДЕГЛОБАЛИЗАЦИИ В МЕЖДУНАРОДНОМ СОТРУ ДНИЧЕСТВЕ РЕГИОНА (НА ПРИМЕРЕ ИРКУТСКОЙ ОБЛАСТИ)

В статье представлена периодизация и общая характеристика международного взаимодействия региона сквозь призму концепции глобализации. Автор приходит к выводу, что для международного сотрудничества региона характерно причудливое сочетание противоположных процессов глобализации и деглобализации.

Ключевые слова: глобализация, деглобализация, Иркутская область, политика, международное сотрудничество. 


\section{THE GLOBALISATION AND DEGLOBALIZATION PROCESSES IN INTERNATIONAL COOPERATION OF THE REGION (ON THE EXAMPLE OF THE IRKUTSK OBLAST)}

The article presents the periodization and general characteristics of the region's international interaction through the prism of the globalization concept. The author concludes that regional international cooperation is characterized by a bizarre combination of opposite processes of globalization and deglobalisation.

Keywords: globalization, deglobalization, Irkutsk region, politics, international cooperation.

Изучение истории участия регионов Российской Федерации в процессах международного сотрудничества представляется важной задачей, в рамках которой особое внимание следует обратить на их вовлеченность в общемировые процессы глобализации и деглобализации, охватывающие современную мировую систему. В начале XXI в. вышли работы, анализирующие схожие проблемы в отношении ряда российских и зарубежных регионов [2; 6], в связи с чем представляется необходимым предпринять подобный обзор применительно и к Иркутской области.

Историю международного сотрудничества Иркутской области РФ можно разделить на три этапа:

Первый этап (1990-1999 гг.) во многом являлся переходным. С позиции макро-анализа, интенсивность глобализации как явления стала проявляться после 1991 г., окончания «холодной войны» и распада одного из центров биполярной системы международных отношений Советского Союза. Значительные области мира, ранее находившиеся вне капиталистической системы, глобальной коммуникации и культуры, оказались включенными в эту систему взаимосвязей. Завершение «холодной войны» разрушило барьеры, сдерживающие западную модель глобализации, и различные регионы мира стали активно включаться в систему мирохозяйственных связей. Не стали исключением и российские регионы, руководство которых активно стремилось развивать международное сотрудничество, искать на внешних рынках новых партнеров, привлекать иностранные инвестиции для развития экономики в условиях сложной экономической ситуации. Крупный зарубежный бизнес стремился освоить новые рынки сбыта, товаров, услуг и технологий, ему требовались минерально-сырьевые ресурсы, в изобилии имевшиеся на территории российских регионов. В Иркутской области в этот период происходила постепенная либерализация внешних контактов, 
ставшая возможной в условиях ослабления контактов с федеральным центром и отсутствия согласованного взаимодействия с соседними регионами. Одним из факторов, способствовавших развитию взаимодействия с иностранными контрагентами, являлось то, что регион был богат природными ресурсами, имел достаточно высокий уровень развития и активный уровень экономического обмена с внешним миром, так как на территории области находился ряд крупных производств, производящих продукцию первого передела (алюминий, целлюлозу и т.п.). Помимо этого, область обладала значительным туристическим потенциалом, а региональные власти во главе с губернатором Ю.А. Ножиковым были заинтересованы в расширении и интенсификации международных контактов. К концу 1990-х гг. у Иркутской области были все возможности для того, чтобы стать одним из «островов глобализации» на территории России, но реализация внешнеэкономических проектов была хаотичной, на взаимодействие с внешними акторами негативно повлиял азиатский экономический кризис 1998 г.

На втором этапе - с 1999 по 2014 гг. - ситуация начинает меняться. Внешние контакты российских регионов постепенно начинает контролировать государство, опасаясь расширения несогласованных контактов с зарубежными контрагентами и действуя в логике построения «вертикали власти». Происходит модернизация законодательства, были приняты Федеральные законы РФ «О координации международных и внешнеэкономических связей субъектов Российской Федерации» (1999 г.), «Об основах государственного регулирования внешнеторговой деятельности» (2003 г.) [1, с. 13]. На федеральном и региональном уровне предпринимались попытки создания структур и институтов развития. Так, на протяжении первого десятилетия XXI в., с 2000 по 2011 гг. действовал Байкальский экономический форум, способствовавший активизации международных контактов Иркутской области, привлечению инвестиций, учреждению новых консульств иностранных государств, было открыто Представительство МИД России (2004 г.), в задачи которого входила работа по согласованию договоров о сотрудничестве с территориями иностранных государств, взаимодействие с зарубежными делегациями [3, с. 294-295]. Уже в этот период в Иркутской области закрепляется негативная модель нестабильности региональной исполнительной власти: за последние двадцать лет в регионе сменилось шесть губернаторов, не считая нынешнего временно исполняющего обязанности губернатора И. И. Кобзева. Указанная модель отрицательно влияла на развитие Иркутской области, приводя к постоянной смене экономических приоритетов, оказывая деструктивное воздействие на динамику внешних контактов и отсутствие долгосрочной стратегии развития.

Под воздействием вышеуказанных тенденций вовлеченность Иркутской области в процессы глобализации претерпевала изменения. 
Происходило постепенное сокращение интенсивности инвестиционного взаимодействия с внешними акторами, в 2011 г. прекратилась работа Байкальского экономического форума, но в то же время в Иркутске были открыты Генеральные консульства Республики Корея и Китайской Народной Республики, стали развиваться внешнеэкономические проекты с государствами Восточной Азии, часть из которых, прежде всего с компаниями из Республики Корея была свернута после 2015 г.

Третий этап международного сотрудничества региона - с 2014 г. по настоящее время - характеризуется сочетанием влияния на международное взаимодействие внешних и внутренних факторов. К внешним следует отнести влияние украинского кризиса 2014 г. и санкционное давление со стороны государств Запада, активизировавшие политику федерального центра по «повороту на Восток», реализовывавшуюся с 2007-2008 гг. в рамках подготовки к проведению саммита АТЭС 2012 в г. Владивостоке [5, с. 55]. Продолжается усиление «вертикали власти», асимметричный характер взаимодействия по линии «центр - регионы» отрицательно воздействует на осуществление международных контактов Иркутской области. На внутреннем уровне фрормируются устойчивые тенденции государственного патернализма. Так, к примеру, региональная политика федерального центра была направлена на реализацию «больших проектов» (наподобие строительства газопровода «Сила Сибири»), непосредственную экономическую отдачу от которых в рамках развития Иркутской области сложно оценить, ведь они носят, в основном, политический характер. Происходит дистанцирование от перспектив активизации внешних связей на региональном уровне, основное внимание уделяется интересам государственных или сырьевых корпораций, отсутствует поддержка внешнеэкономических инициатив, генерируемых средним или малым бизнесом.

С 2014 г. характер участия Иркутской области в процессах международного сотрудничества видоизменяется. Тенденции глобализации, активно воздействовавшие на российские регионы в 1990-2000-е гг., трансформируются. Санкционная политика стран Запада негативно влияет на интенсивность торговли товарами, услугами и инвестициями. Расширяется сотрудничество с восточными партнерами, в частности, с Китайской Народной Республикой, идут дискуссии о подключении восточных регионов Российской Федерации к инициативе «Экономического пояса Шелкового пути», выдвинутой Китайской Народной Республикой, представляющей собой иной, незападный, вариант глобализации. Региональные власти Иркутской области и бизнес в целом нейтральны по отношению к интенсивному развитию проектов с участием иностранных инвесторов, но активно развивается сфера услуг, в особенности туристический сектор, фрактором роста выступает рекреационный потенциал оз. Байкал. 
В отношении Иркутской области, как и для регионов российского Дальнего Востока, актуален тезис авторов коллективной монографии «Тихоокеанская Россия в интеграционном пространстве Северной Пацифики в начале XXI века» относительно того, что за прошедшие тридцать лет не удалось «...устранить инфраструктурные и демографрические ограничители, сформировать среду крупных и конкурентоспособных предпринимателей в регионе, разорвать тесную, а иногда и полукриминальную связь региональных политических элит с местным бизнесом. Следствием этого стали неэффективная организация и сопровождение экономических связей региональными бюрократическими и политическими элитами, их хаотичность и нестабильность, крайняя осторожность соседей по региону при налаживании взаимодействия с Россией» [4, с. 383].

В отличие от регионов Дальнего Востока, в Восточной Сибири отсутствовали масштабные вложения фредеральной власти в развитие инфраструктуры, не делались попытки развития производств, которые могли бы опираться на создание продукции с высокой добавленной стоимостью. Формирование кластеров, способных создавать новые технологии или инновационные продукты, тоже затягивалось - региональные власти были не способны развивать проекты такого рода самостоятельно, а крупный бизнес в них был не заинтересован. Федеральный центр вмешался и во внутреннюю логику взаимодействия между регионами Восточной Сибири, к которым относится и Иркутская область, после того, как Республика Бурятия и Забайкальский край в ноябре 2018 г. указом Президента РФ были отнесены к Дальневосточному федеральному округу, в административном контексте они перестали относиться к Сибири. Это приводит к стагнации уже наработанных межрегиональных связей, соседние регионы не объединяют усилия для повышения инвестиционной привлекательности и позиционирования во внешнем пространстве.

Сочетание указанных фракторов привело к тому, что богатый природными ресурсами, но удаленный от транспортных путей регион - Иркутская область, оказался вне проектов развития, что способствовало консервации и воспроизводству периферийного статуса, в том числе и в отношении связей с внешними контрагентами, интенсивному оттоку человеческих ресурсов («западный дрейф»). На сегодняшний день отсутствуют тщательно разработанные программы и стратегии развития региона, а те из них, которые были приняты, не были полноценно реализованы. Экономические элиты Иркутской области устойчивы, но не консолидированы, они зависят от фредеральных трансфертов и негативно воспринимают иностранные компании, пытающиеся реализовать собственные проекты на территории региона, рассматривая их в качестве конкурентов. 
Следует согласиться с мнением, что «... российский проект интеграции в ATP оказался, по сути, бессодержательным. Он фрактически был сведен к развитию экономических и политических связей России с несколькими ключевыми азиатскими партнерами и расширению еe формального участия в региональных организациях» [4, с. 381].

Таким образом, следует констатировать, что для международного сотрудничества региона характерно причудливое сочетание противоположных трендов глобализации и деглобализации, в последние годы происходит усиление последней тенденции - инвестиционная привлекательность Иркутской области для зарубежных инвесторов снижается, проекты развития, в рамках которых возможна кооперация с иностранными партнерами остаются нереализованными.

\section{Список использованной литературы и источников}

1. Бусыгина Е. М. Субъекты федерации в международном сотрудничестве / Е. М. Бусыгина, Е. Б. Лебедева // Аналитические записки НКСМИ МГИМО(У) МИД России. - 2008. - Вып. 3 (32). - 28 с.

2. Международная интеграция российских регионов / отв. ред. И. И. Курилла. - Москва : Логос, 2007. - 304 с.

3. Олейников И. В. Иркутская область: сотрудничество со странами АТР в начале XXI в. / И. В. Олейников // Тихоокеанская Россия в межцивилизационном и общероссийском пространстве: прошлое, настоящее, будущее (Седьмые Крушановские чтения, 2011 г.). - Владивосток : Дальнаука, 2013. - С. 293-298.

4. Тихоокеанская Россия в интеграционном пространстве Северной Пацифики в начале XXI века: опыт и потенциал регионального и приграничного взаимодействия / под ред. В. Л. Ларина. - Владивосток : ИИАЭ ДВО РАН, 2017. $386 \mathrm{c}$.

5. Чечевишников А. Л. Восточный вектор российской политики и перспективы развития Дальнего Востока и Сибири / А. Л. Чечевишников // Международные процессы. - 2014. - Т. 12, № 1-2. - С. 51-75.

6. Kuznetsov A. S. Theory and Practice of Paradiplomacy: Subnational Governments in International Affairs / A. S. Kuznetsov. - London-New York: Routledge, 2015. - $174 \mathrm{p}$.

\section{Информация об авторе}

Олейников Илья Васильевич — канд. ист. наук, доцент, кафедра политологии, истории и регионоведения, исторический фракультет, ФГБОУ ВО «Иркутский государственный университет», 664003, г. Иркутск, ул. Чкалова, 2, e-mail: oleynikov@ isu.ru.

\section{Author}

Ilya V. Oleynikov - PhD in History, associate professor, Chair of Political Science, History and Regional Studies, History Faculty, Irkutsk State University, Chkalov str. 2, Irkutsk, 664003, e-mail: oleynikov@isu.ru. 